\author{
Matgorzata Leszczyńska, \\ Beata Kasprzyk \\ University of Rzeszow
}

\title{
CHANGES IN THE INCOMES AND EXPENDITURES OF HOUSEHOLDS IN POLAND AND THEIR REGIONAL RELATIONS
}

The article assesses the financial situation of households in 2000-2019 in prospect of changes of incomes and expenditures in Poland. It has been assumed, as a point of reference, that dispersion of the analysed processes is dependent on geographical area-therefore regional scale was applied. To the analysis and comparison the data from the researches on households budgets performed by GUS were used. Adopting simultaneously an econometric approach (considering the time (years 2000-2019) as independent, explanatory variable) analytical trend functions were estimated. A retrospective analysis of the incomes and expenditures of the population of Poland indicates the growing trends. Regional comparative analysis of households allows to draw conclusions that level of economic condition is very diversified.

Key words: income and expenditure, households, economic standard of living, regional analysis, personal finances, social inequalities

JEL codes: D12, D31, I31, R2

\section{Introduction}

Economic prosperity of a society is a complex economic and social category ${ }^{1}$. Widely known, indirect dimensions of macroeconomic type are measures, such as ${ }^{2}$ : GDP per capita, national income, individual income of population or inflation rate. The measures are applied as instruments for comparison of prosperity, particularly among countries or regions $^{3}$. In more detailed economic analyses, in measuring life quality and its diversification among societies, in the economic dimension on a microeconomic scale, various household income variants are employed ${ }^{4}$. In that regard, a basic indicator is household's available income, which is gross income with the exclusion of fixed financial liabilities of tax, including all current income of a household within a specified

1 E. Babula, T. Kamińska: Uwarunkowania dobrobytu w sferze realnej, Published by: Wydawnictwo Uniwersytetu Gdańskiego, Gdańsk 2013; M. Zaremba: Dobrobyt społeczny - problemy metodologiczne i definicyjne, „Nierówności Społeczne a Wzrost Gospodarczy” 4/2016, pp. 323-331.

${ }^{2}$ G. Wronowska: Dobrobyt - ujęcie teoretyczne i pomiar, Zeszyty Naukowe „Cracow Review of Economics and Management" 12 (948) /2015, pp. 5-16.

3 A. Blajer-Gołębiewska, L. Czerwonka (eds.): Mikro- i makroekonomiczne aspekty tworzenia dobrobytu, Published by: Uniwersytet Gdański, Gdańsk 2014; D. Kahneman: International Differences in Well-Being, Series in Positive Psychology, Oxford University Press, New York 2010.

${ }^{4}$ Comp. e.g.: W. Ostasiewicz: Dobrobyt i jakość życia: badania w Polsce i zagranicą, „Śląski Przegląd Statystyczny" 11/2017, pp. 243-258; Cz. Bywalec: Gospodarstwo domowe: ekonomika, finanse, konsumpcja, Wydawnictwo Uniwersytetu Ekonomicznego w Krakowie, Kraków 2017. 
period of time ${ }^{5}$. Such income is allocated to expenditures (consumer goods and services and other expenses), as well as savings accumulation (unrealised expenditures). As the realised expenditures are allocated to the satisfaction of household needs, together with the income they constitute an image of household economic prosperity.

Due to the above definitions, the aim of the present research is an assessment of the material situation of households in the time period (2000-2019 years $)^{6}$, in the range of the financial categories of economic prosperity of pecuniary type, i.e. income and expenditure on an all-Poland scale. The next cognitive aim of the article is the analysis of the scale and the level of diversification of regional prosperity of households, with particular focus on the so called eastern Poland regions. The answer to the question about an objective level of income and expenditure, as well as establishing relations between those values in particular regions of Poland is very significance. Such analysis will also allow us to establish the real level of economic prosperity of the population and its diversity, which is especially important for overall socio-economic development ${ }^{7}$.

This article is a partial contribution to the literature and empirical approach of the main determinants of households welfare. We hope that this publication will prove to be a valuable source of knowledge for many institutions and individuals interested in the presented issues.

\section{Research material and methodology}

The present analysis of the living conditions of the population and the conclusions concerning the assessment of the influence of selected factors on economic prosperity on the formation of the level and diversification of households welfare was based on the data received from household budget research carried out by GUS (Polish Central Statistical Office). The analysis of incomes and expenditures of households was made in a dynamic view in the long term time (2010-2019 years).

Adopting simultaneously an econometric approach ${ }^{8}$ (considering the time variable as the model clarifying variable) analytical functions of the trend for the studied variables were estimated. Based on empirical data an assessment of structural and stochastic parameters of linear function of the trend for income and expenditure per person (in real approach) was estimated.

The assumed point of reference of the article is, that the dispersion and polarisation of basic categories of economic prosperity of income and its derivatives, among which is expenditure, is mainly dependent on geographical area of residence. Verification of the authenticity of this hypothesis on the basis of empirical data, proves to concern only lower territorial units (district, size of the town), as well as province scale and most of all

\footnotetext{
${ }^{5}$ Zeszyt metodologiczny. Badanie budżetów gospodarstw domowych, GUS, Warszawa 2018.

${ }^{6}$ Researches in this area carried out for the years 2000-2010 can be found in the paper: M. Leszczyńska, B. Kasprzyk: Dochody i wydatki jako determinanty dobrobytu ekonomicznego gospodarstw domowych w Polsce -ujęcie regionalne, „Nierówności Społeczne A Wzrost Gospodarczy”, 2012/28, pp. 263-273.

${ }^{7}$ Krajowa Strategia Rozwoju Regionalnego 2010-2020: Regiony, Miasta, Obszary wiejskie, Monitor Polski 2011, no. 36, pos. 423; Uchwała nr 8 Rady Ministrów z dnia 14 lutego 2017 r. w sprawie przyjęcia Strategii na rzecz Odpowiedzialnego Rozwoju do roku 2020 (z perspektywą do 2030 r.), Monitor Polski 2017, pos. 260; Krajowa Strategia Rozwoju Regionalnego 2010-2020: Regiony, Miasta, Obszary wiejskie, Monitor Polski 2011, no. 36, pos. 423.

${ }^{8}$ S.M. Kot, J. Jakubowski, A. Sokołowski: Statystyka, Difin S. A. 2011, pp. 337-339.
} 
- regional. Therefore, the analysis included households spatially related to the macroregions of Poland. Out of 16 Polish provinces 7 regions were selected (following GUS methodology) with the following provincial composition: Central region (voivodships: łódzkie, świętokrzyskie); Southern region (voivodships: Małopolskie, Śląskie); Eastern region (voivodships: Lubelskie,Ppodkarpackie, Podlaskie); Northernwestern region (voivodships: Lubuskie, Wielkopolskie, Zachodniopomorskie); Southernwestern region (voivodships: Dolnośląskie, Opolskie); Northern region (voivodships: Kujawsko-pomorskie, Pomorskie, Warmińsko-mazurskie); Macroregion: voivodships: (only Mazowieckie).

The analysis was particularly focused on the eastern region and presents the discussed economic categories related to the material situation in this region in relation to the all-Poland, as well as to other regions.

\section{Results of the research}

Diverse average monthly incomes and the expenditures are strictly correlated with specific socio-economic-demographic conditions of individual households ${ }^{9}$. Some, of the main differential factors include: belonging to a socio-economic group, type of professional activity, level of education of the head of a household, biological family type, composition or the age of the household members.

However, economic standard of living is a category which considerably diversifies households, changeable in the area of their specific features, as well as in time. A significant initial element of the analysis seems to be a retrospective research, presenting a 'historic' image of the formation of the basic categories of economic prosperity, represented by incomes and expenditures of households. Fig. 1 presents the overall level of nominal income and expenditure per person in Poland. Tab. 1 presents ratios which indicate interpretation of the direction and the strength of the dynamics of such phenomena, and also their mutual relations.

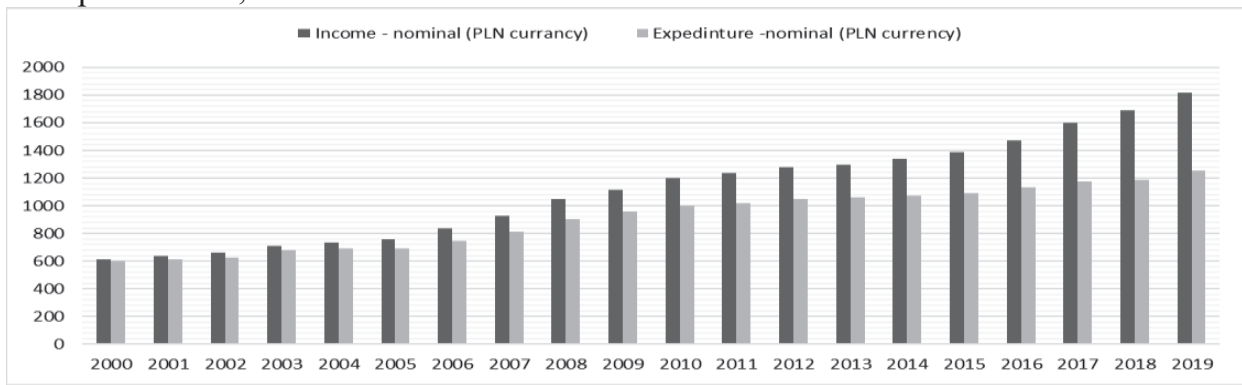

Figure. 1. Nominal income and expenditure per person in households in Poland in 2000-2019 Source: Own study on the basis of: www.stat. gov.pl [accessed May 19, 2021].

In the first year of analysed period - year 2000, average monthly disposable income per person in Poland nominally reached 611 PLN. The nominal income was systematically increasing in the following years. In the year 2010 the income was about

\footnotetext{
${ }^{9}$ D. Abramczyk: Społeczne, demograficzne, ekonomiczne i geograficzne uwarunkowania zarządzania budżetem domowym w Polsce, Uniwersytet Marii Curie-Skłodowskiej w Lublinie, „Finanse i Prawo Finansowe" 3(19)/2018, pp. 9-24.
} 
1200 PLN and nominally nearly doubled the one of the year 2000, and to lately reached the level of 1819 PLN in the year 2019. Assessment of expenditure dynamics in the analysed period is similar. Average monthly disposable expenditure per person in Poland - in a nominal approach - was increasing from the level of 599 PLN in 2000 to 1252 PLN in 2019.

Table 1. Dynamics of average monthly disposable income and expenditure per person in households in Poland $2000-2019$

\begin{tabular}{|c|c|c|c|}
\hline \multirow[t]{2}{*}{ Year } & Income & Expenditure & \multirow{2}{*}{$\begin{array}{c}\text { Expenditure/Income } \\
\text { (in } \%)\end{array}$} \\
\hline & \multicolumn{2}{|c|}{ Dynamics $2000=100($ in $\%)$} & \\
\hline 2000 & 100,0 & 100,0 & 98,0 \\
\hline 2001 & 104,3 & 102,2 & 95,9 \\
\hline 2002 & 108,7 & 104,3 & 94,1 \\
\hline 2003 & 116,5 & 113,2 & 95,1 \\
\hline 2004 & 120,3 & 116,0 & 94,4 \\
\hline 2005 & 124,5 & 115,2 & 90,5 \\
\hline 2006 & 136,7 & 124,4 & 89,1 \\
\hline 2007 & 152,0 & 135,2 & 87,1 \\
\hline 2008 & 171,2 & 150,9 & 86,3 \\
\hline 2009 & 182,3 & 159,8 & 85,7 \\
\hline 2010 & 196,6 & 166,6 & 83,1 \\
\hline 2011 & 202,1 & 170,5 & 82,7 \\
\hline 2012 & 209,2 & 175,5 & 82,2 \\
\hline 2013 & 212,6 & 177,3 & 81,8 \\
\hline 2014 & 219,3 & 179,5 & 80,2 \\
\hline 2015 & 226,8 & 182,1 & 78,8 \\
\hline 2016 & 241,4 & 189,0 & 76,7 \\
\hline 2017 & 261,5 & 196,3 & 73,6 \\
\hline 2018 & 277,1 & 198,2 & 70,1 \\
\hline 2019 & 297,7 & 209,0 & 68,8 \\
\hline
\end{tabular}

Source: Own compilation and calculation on the basis of: www.stat.gov.pl [accessed May 19, 2021].

Relation between expenditure and income should be assessed as an advantage. In a view of this ratio a significant decreasing trend can be noticed.

Considering the changes of incomes and expenditures, the appropriate approach, which is more precise and credible, should take account of real level of variables being under these researches (comp. fig. 2 and tab. 2).

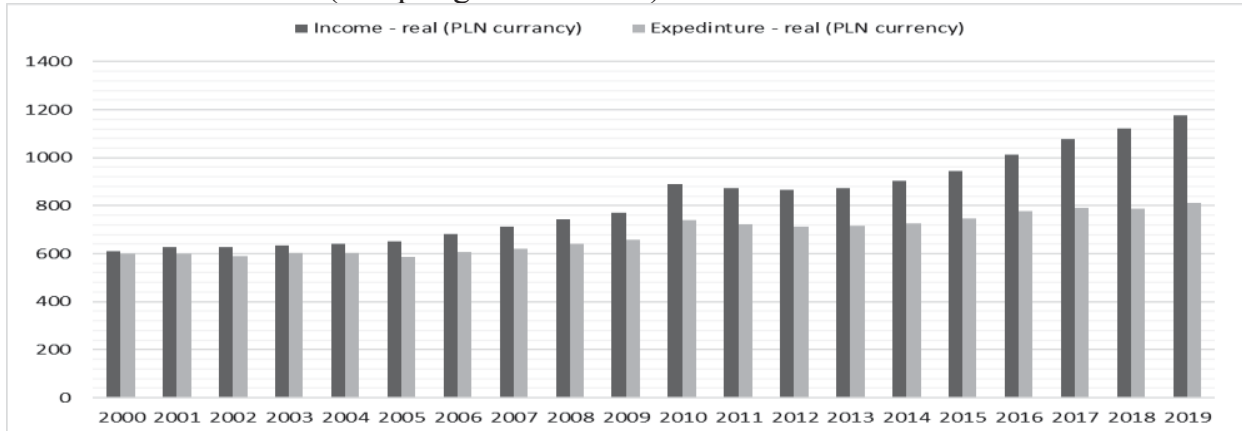

Figure. 2. Real income and expenditure in total per person in households in Poland 2000-2019 Source: Own study on the basis of: www.stat. gov.pl [accessed May 19, 2021]. 
The values of studied variables, in this case significantly lower - in real approachindicates that over the period of studied 20 years the real income per person had been raised only by $92,8 \%$ (nominally by $198,0 \%$ ), while expenditures only by $35,2 \%$ (nominally by $109,0 \%$ ).

Table 2. Dynamics of real* income and expenditure per person in households in total in Poland 2000 - 2019

\begin{tabular}{|c|c|c|c|c|}
\hline \multirow[t]{2}{*}{ Year } & \multicolumn{2}{|c|}{ Real income } & \multicolumn{2}{|c|}{ Real expenditure } \\
\hline & $\begin{array}{c}\text { Dynamics } \\
\text { [year 2000=100 } \\
\text { (in \%)] }\end{array}$ & $\begin{array}{c}\text { Dynamics } \\
\text { [previous year=100 } \\
\text { (in \%)] }\end{array}$ & $\begin{array}{c}\text { Dynamics } \\
\text { [year } 2000=100 \text { (in \%)] }\end{array}$ & $\begin{array}{c}\text { Dynamics } \\
\text { [previous year }=100 \text { (in } \\
\%)]\end{array}$ \\
\hline 2000 & 100,0 & - & 100,0 & - \\
\hline 2001 & 102,6 & 102,6 & 100,4 & 96,8 \\
\hline 2002 & 102,8 & 100,2 & 98,6 & 100,2 \\
\hline 2003 & 103,9 & 101,1 & 100,9 & 107,6 \\
\hline 2004 & 104,7 & 99,8 & 100,8 & 99,0 \\
\hline 2005 & 106,4 & 101,4 & 98,2 & 97,2 \\
\hline 2006 & 111,5 & 108,5 & 101,3 & 106,8 \\
\hline 2007 & 116,7 & 108,6 & 103,7 & 106,0 \\
\hline 2008 & 121,6 & 108,0 & 107,0 & 107,1 \\
\hline 2009 & 125,9 & 103,0 & 110,1 & 102,3 \\
\hline 2010 & 145,7 & 105,0 & 123,6 & 101,6 \\
\hline 2011 & 142,9 & 98,6 & 120,5 & 98,0 \\
\hline 2012 & 141,7 & 99,9 & 118,9 & 99,4 \\
\hline 2013 & 143,0 & 101,7 & 119,3 & 99,4 \\
\hline 2014 & 148.0 & 103,2 & 121,0 & 101,6 \\
\hline 2015 & 154,8 & 104,3 & 124,3 & 102,1 \\
\hline 2016 & 165,8 & 107,0 & 129,7 & 104,3 \\
\hline 2017 & 176,1 & 106,3 & 132,2 & 101,9 \\
\hline 2018 & 183,6 & 104,3 & 131,2 & 99,3 \\
\hline 2019 & 192,8 & 105,0 & 135,2 & 103,1 \\
\hline
\end{tabular}

* Statistics on income and expenditure in a real view has been reduced to comparability (of constant prices). The levels of nominal incomes have been corrected with inflation rate - the price index of consumer goods and services was used).

Source: Own compilation and calculation on the basis of: www.stat.gov.pl [accessed May 19, 2021].

In the analysed period the rate of the changes of real incomes was higher, than the one of real expenditures. Such tendency is indicated by rates changes in both, a nominal and a real view. Real income and expenditure tempo growth in the years 2000-2019 was $3,52 \%$ (for income) and $1,67 \%$ (for expenditure), respectively. It can be noted, that the years 2011 - 2013 characterized a slight decline in real income, and a short-term stagnation. Only thereafter the incomes generated higher internal demand, and hence the consumer goods and services consumption growth. It needs to be reflected that the child benefit ('Rodzina 500+' (Family 500+)) granted for some families and introduced on 01.04.2016, represented $16,8 \%$ of disposable income per person in the households entitled. Further, it translates into the growth of income and prosperity of households in an economic view, while the effects in the structure of income and expenditure are to be seen in the years upcoming. 
Fig. 3 presents the general comparative overview of differences in value of income and expenditure in a nominal and a real view.

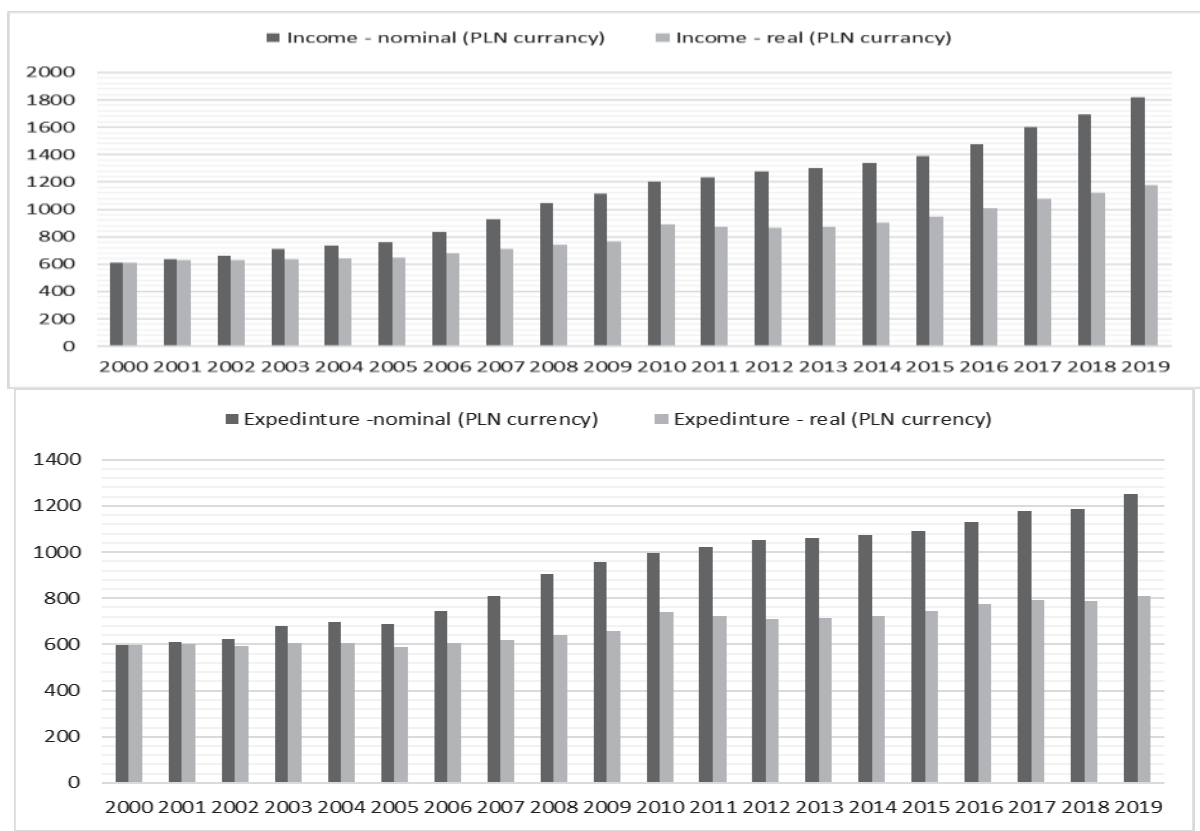

Figure 3. Nominal and real income and expenditure in total per person in households in Poland 2000-2019 Source: Own compilation and calculation on the basis of: www.stat.gov.pl [accessed May 19, 2021].

The next analysis is the building the time series models due to estimation of a linear functions, carried out below. Time series processes are often described by dynamic linear models:

$$
Y_{t}=\alpha_{0}+\alpha_{1} t+\varphi_{t}
$$

The empirical time series is treated as a sample on periods of the studied independent variable $(t=1,2, \ldots)$, model is given below:

$$
\hat{\mathrm{y}}_{t}=a_{0}+a_{1} t+e_{t}
$$

where $y_{t}$ is an observed response (past observations) and $t$ includes contemporaneous values of observable predictor. The coefficient $\alpha_{l}\left(a_{l}\right)$ represent the marginal contributions of individual predictor to the variation in $y_{t}$. The term $\zeta_{t}\left(e_{t}\right)$ is a catch-all for differences between predicted and observed values of $y_{t}$. These differences are due to process fluctuations, measurement errors and model misspecifications (for example, omitted predictors or nonlinear relationships between $t$ and $y_{t}$. Basic stochastic parameters of models are: $R^{2}$ - R-squared - coefficient of determination (normally ranges from 0 to 1 ) and $s_{e^{-}}$standard error of the estimate ${ }^{10}$.

${ }^{10}$ A. D. Aczel: Statystyka w zarządzaniu, PWN, Warszawa, 2000, pp. 624-627; M. Cieślak: Prognozowanie gospodarcze. Metody i zastosowania, PWN, Warszawa, 2012, pp. 76-78. 
Adopting simultaneously an econometric approach (considering the time variable of 2000-2019 and in the model 'time' as the clarifying variable), analytical trend functions for the studied variables has been estimated (in real view). Based on empirical data an assessment of structural and stochastic parameters of linear trend functions per person (the incomes - function 1 and expenditures - function 2) was estimated. The theoretical formulas of the analytical functions and the results of stochastic parameters are listed below:

$$
\begin{gathered}
\hat{\mathbf{Y}}_{\mathbf{t} \text { (incomes) }}=\mathbf{2 9 , 3 9} \boldsymbol{t}+\mathbf{5 1 3}, \mathbf{3 1} \\
(1,72) p=0,00(20,66) p=0,00 \\
s_{e}=44,47 ; R^{2}=0,9416(F=290,42 ; p=0,0000) \\
\hat{\mathbf{Y}}_{\mathbf{t} \text { (expenditures) }}=\mathbf{1 2 , 5 8} \boldsymbol{t}+\mathbf{5 4 9 , 8 2} \\
(0,92) p=0,00(10,99) p=0,00 \\
s_{e}=23,66 ; R^{2}=0,9127(F=188,13 ; p=0,0000)
\end{gathered}
$$

Due to the correct fitting of both functions to real data (high value of determination indicators $R^{2}$ and statistical significance of structural parameters $p=0000$ ), we may assume, that during the analysed years, average income per person has been increased annually by 29,39 PLN, while the expenditure growth was considerably slower, respectively 12,58 PLN. On fig. 4. assessment of "the diversity gap" for the real disposable income and expenditure in Poland is presented. The values have been calculated as an absolute levels, the findings shows important conclusions.

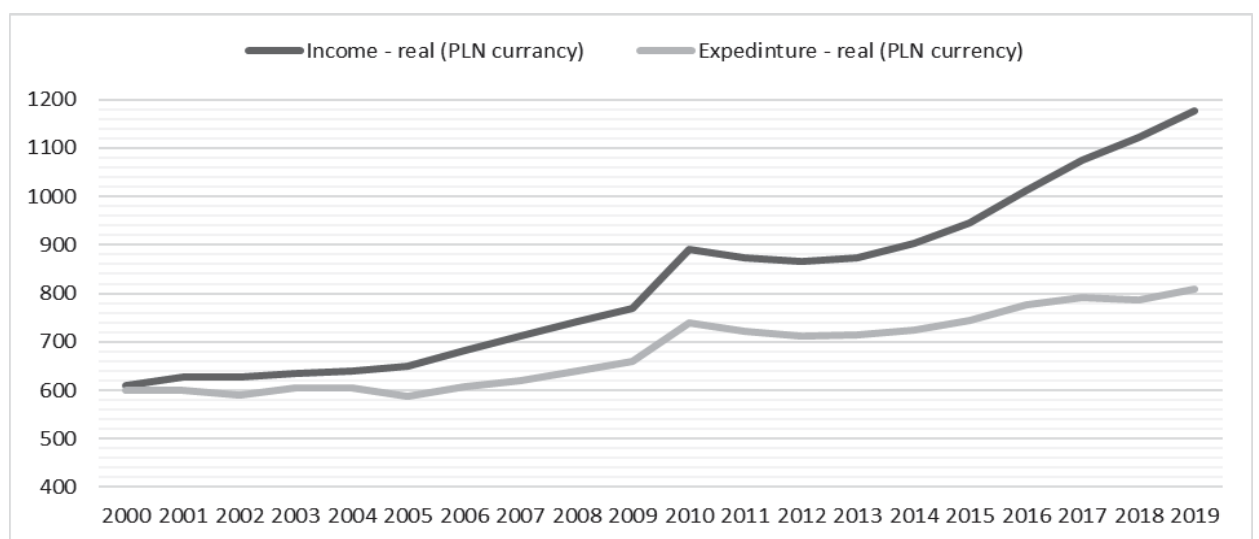

Figure. 4. The diversity gap - real disposable income and expenditure, in total per person in Poland 2000-2019 (PLN)

Source: Own elaboration based on data published by Central Statistical Office of Poland www.stat.gov.pl [accessed May 19, 2019].

We observe the gradual growth in deviation between income and expenditure per person in the period analysed. While at the beginning, in 2000 and to 2004, income and expenditure were nearly equal and in 2004 an absolute difference was only 36 PLN. In 2010 it was already 201,38 PLN to eventually reach 567 PLN in 2019 (although real only 368 PLN).

As a consequence of mutual divergence in income and expenditure, it turns out, that the percentage participation of total expenditure in disposable income per person in 
households, during the last decade was decreasing systematically (tab. 1) from $98 \%$ in 2000 to $69 \%$ at the end of the analysed period. Such changes indicate not only the increasing significance of accumulation in households, but also the better incomeexpenditure situation, particularly visible in comparison 2010 and 2019. The growth of incomes allowed the growth of economic prosperity. The material situation of households has been gradually improved, and next, this positive trend allowed to increase the savings scale, drawn from the current incomes. Notably, such tendencies are convergent with the trends occurring in countries with high economic development.

The next point of analysis for the variables is a comparative analysis in the regions of Poland in 2019. The analysis is particularly focused on the Eastern region and the relations of the discussed economic categories of the material situation in that region in relation to the all-Poland data, as well as data to other regions. The values of incomes and expenditures comparison in regions in 2019 is presented on fig. 5.

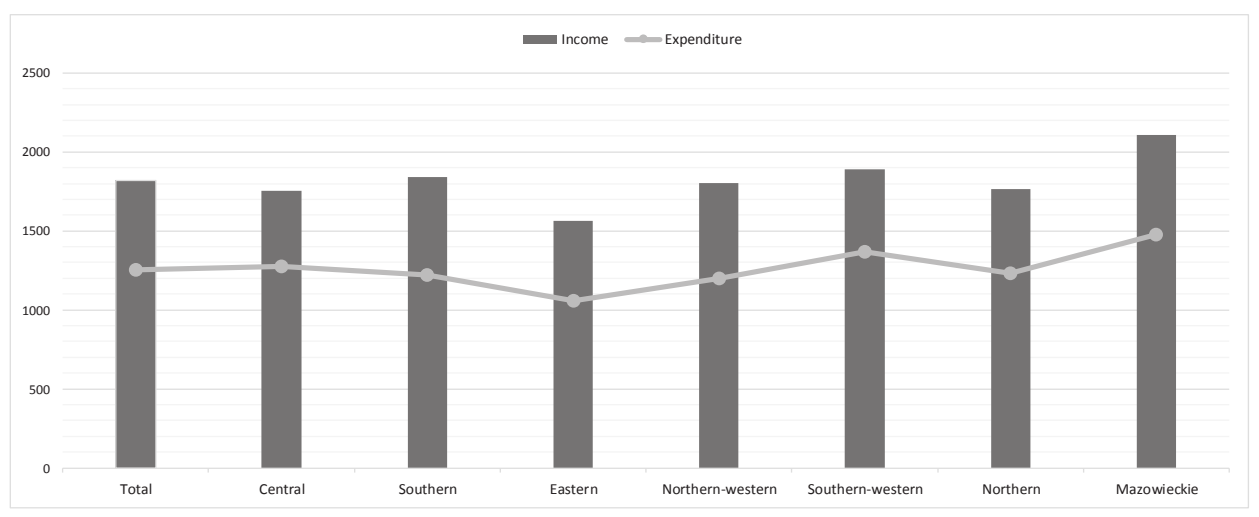

Figure. 5. Average monthly disposable income and expenditure, in total, per person in households per regions of Poland in 2019 (PLN)

Source: Own elaboration based on data published by Central Statistical Office of Poland www.stat.gov.pl [accessed May 19, 2021].

Empirical data undeniably points to the fact, that an average economic condition of households depends on the region of residence ${ }^{11}$. In the Eastern region, average income, as well as expenditure, is the lowest in comparison to the all-Poland and individual regions. The situation was the same, in 2010 and in 2019. We may still observe these variations, the average income in this region in 2019 were established on the level of 1566 PLN, while the average income in Poland levelled 1819 PLN. Such situation results in concurrent lowest total expenditure amounting barely to 830 PLN in 2010 (monthly per person in a household). In the Eastern region expenditures in 2019 were at the level of 1057 PLN, while the average national was 1252 PLN. Similarly, the lowest absolute discrepancy between income and expenditure also concerns this region, where it

${ }^{11}$ Comp. e.g. M. Grzywińska-Rąpca, M. Kobylińska: Regionalne zróżnicowanie dochodów gospodarstw domowych. „Wiadomości Statystyczne”, 64, 12/2019, pp. 46-57; T. Panek.: Jakość życia gospodarstw domowych w Polsce w układzie wojewódzkim. „Zeszyty Naukowe Instytutu Statystyki i Demografii SGH”, 2015/46, pp.1-111; Regionalne zróżnicowanie jakości życia w Polsce, GUS, Warszawa 2017. 
amounted to 159 PLN in 2010 and, in 2019, though it raised to the level of 509 PLN, it continuously indicates the lowest accumulation of savings (unrealised expenditures). While in 2010 the highest range of the analysed prosperity categories concerns the Central and Northern region (respectively 245 PLN and 239 PLN), it referred to the Northern-western region, Southern region and macroregion voivodship Mazowieckie in 2019 (respectively 605 PLN, 623 PLN and 632 PLN $^{12}$. The dispersions and quantitative inter-regional relations are presented in fig. 6. It specifies absolute fluctuations within the researched categories: incomes-expenditures per person in 2019.

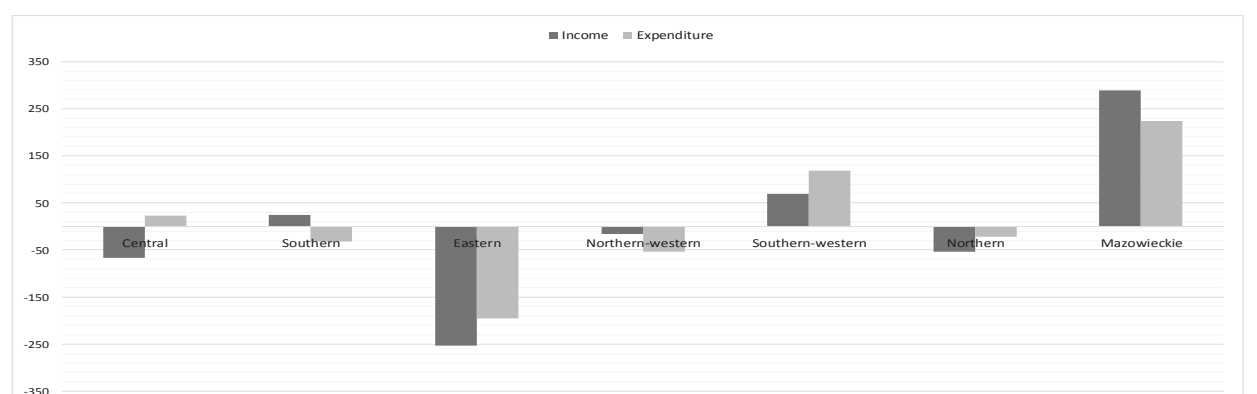

Figure 6. Average monthly disposable income and expenditure per person in households (regions of Poland) in 2019 (PLN)

Source: Own elaboration based on data published by Central Statistical Office of Poland www.stat.gov.pl [accessed May 19, 2021].

While in 2010 in the Central region (in an absolute level), income was higher than the average by about 270 PLN, with expenditure by about 220 PLN, in the Eastern region these values were lower than the average, and the difference amounts were respectively: 204 PLN for income and 162 PLN for expenditure. At the same time, income in that region was lower by as much as 474 PLN, with expenditure by 383 PLN, in comparison to parallel values reached in the Central region ${ }^{13}$. While in 2019 , income and expenditure in the Eastern region were lower respectively by 253 PLN and 198 PLN concerning the national average, concerning the region Mazowieckie the income was lower by $25,7 \%$ and expenditure by $28,4 \%$. The incomes, as well as the expenditures, in the Eastern region, were lower by $13,4 \%$ and $15,6 \%$ in comparison to parallel average national values. The decidedly 'remarkable in plus' region, in a regional comparative analysis is the region Mazowieckie. The 'in minus' rating clearly shows the Eastern region to be significantly in the lead with the highest negative material categories, in relation to the national scale (tab. 3 ).

Notably, on a regional scale, a significant diversification is still observed within the analysed categories of economic prosperity ${ }^{14}$. Whereas expressed in percentages the lowest average income in 2010 constituted only about $68,0 \%$ of the highest income

12 comp. Regiony Polski, GUS, Warszawa, years 2011, 2020; Budżety gospodarstw domowych, GUS, Warszawa, year 2011, 2020, p.122, p.138.

${ }^{13}$ Budżety gospodarstw domowych, GUS, Warszawa, year 2011.

${ }^{14}$ comp. W. Pizło, A. Mazurkiewicz-Pizło.: Regionalne zróżnicowanie dochodów gospodarstw domowych w Polsce, ,Roczniki Naukowe Stowarzyszenia Ekonomistów Rolnictwa i Agrobiznesu” 16 96)/2014, pp. 397 402. 
achieved by households, in 2019 this relation raised up to 74,3\%. It appears, identical range concerned the average expenditures in 2010 and $2019^{15}$.

Table 3. Relation and rating of monthly disposable income and expenditure, in total, per person in households as per regions (Poland $=100$, in \%) and basic characteristics of households in 2019

\begin{tabular}{|c|c|c|c|c|c|c|c|c|}
\hline \multirow[b]{2}{*}{ Regions } & \multicolumn{2}{|c|}{ Income } & \multicolumn{2}{|c|}{ Expenditure } & \multirow{2}{*}{$\begin{array}{l}\text { Expenditu } \\
\text { re/income } \\
\quad(\text { in } \%)\end{array}$} & \multirow{2}{*}{$\begin{array}{l}\text { Populati } \\
\text { on } \\
\text { structure } \\
\text { (in \%) }\end{array}$} & \multicolumn{2}{|c|}{$\begin{array}{l}\text { Average } \\
\text { value }\end{array}$} \\
\hline & $\begin{array}{c}\text { Poland } \\
=100\end{array}$ & Position* & $\begin{array}{l}\text { Poland } \\
=100\end{array}$ & Position* & & & $\begin{array}{c}\text { Pers } \\
\text { ons }\end{array}$ & $\begin{array}{l}\text { Equival } \\
\text { ent } \\
\text { units } \\
\text { units** }\end{array}$ \\
\hline Total & 100 & - & 100 & - & 68,8 & 100 & 2,61 & 1,72 \\
\hline Central & 96,3 & 6 & 101,8 & 3 & 72,8 & 9,7 & 2,56 & 1,71 \\
\hline Southern & 101,3 & 3 & 97,4 & 5 & 66,2 & 20,1 & 2,61 & 1,72 \\
\hline Eastern & 86,1 & 7 & 84,4 & 7 & 67,4 & 14,5 & 2,75 & 1,79 \\
\hline $\begin{array}{l}\text { Northern- } \\
\text { western }\end{array}$ & 99,1 & 4 & 95,7 & 6 & 66,4 & 15,5 & 2,65 & 1,74 \\
\hline $\begin{array}{l}\text { Southern- } \\
\text { western }\end{array}$ & 103,8 & 2 & 109,4 & 2 & 72,6 & 10,3 & 2,50 & 1,67 \\
\hline Northern & 97,0 & 5 & 98,2 & 4 & 69,7 & 15,1 & 2,63 & 1,73 \\
\hline $\begin{array}{l}\text { Mazowiecki } \\
\mathrm{e}\end{array}$ & 115,9 & 1 & 117,9 & 1 & 70,0 & 14,7 & 2,51 & 1,67 \\
\hline
\end{tabular}

* 1- top position; 6- lowest position

** Equivalent units illustrate the influence of demographic composition of a household on its maintenance expenses (modified equivalence scale OECS was applied in the research).

Source: Own elaboration based on data published by Central Statistical Office of Poland www.stat.gov.pl [accessed May 29, 2018; accessed May 19, 2021].

Definitely highest income and expenditure feature in the macroregion Mazowieckie, where they were about 15,9\% higher than their national average. Although in the Southern-western region income, as well as expenditure, was higher than the national average, but such dominance for both categories was much lower and was respectively $3,8 \%$ and nearly $9,4 \%$. Incomes and expenditures similar to the national scale featured in the northern and southern regions. The last position in all compared categories belongs to the Eastern region (including voivodships: Lubelskie, Podkarpackie and Podlaskie). The span in respect to the all-Poland scale for the two analysed prosperity measures were respectively: 13,9\% for income and 15,6\% for expenditure. It is worth to mention, that the Podkarpackie voivodship noted the lowest income and expenditure rates. In 2010, the income in this province was by about $24 \%$ lower than the national average, and the expenditure was by $17,0 \%$ lower than an average of households. However, over the analysed period, this span expressed in percentages increased for incomes, but raised for expenditures. While the distance in respect to income in 2019 was $19,1 \%$, the gap in regard to expenditure in comparison to all-Poland average was $18,8 \%{ }^{16}$.

The highest percentage share of expenditure in income in 2010 was noted in the Southern region - nearly $86 \%$, the lowest in the Northern region - less than $80 \%$, with a national average equal $83 \%$. While in 2019 , the highest share of expenditure in income

${ }^{15}$ comp. Regiony Polski, GUS, Warszawa, years 2011, 2020.

16 comp. Budżety gospodarstw domowych, GUS, Warszawa, year 2011, 2020; Regiony Polski, GUS, Warszawa, year 2011, 2020;. 
was noted in the Southern-western region and Central region (nearly $73 \%$ ), and the lowest in the Northern-western and Southern region (less than 66\%). The differences within the scope of expenditure share in income present in Poland and their changes in the regions along the period of 2010-2019 show the significant scale of material economic situation diversification. Nevertheless, a gradual fall of such indicator shows actual progress in that respect. ${ }^{17}$

Apparently, the rating within income and expenditure for the Eastern region places it towards the end of the comparison on a national scale. Notably, about $15 \%$ of the researched population resides in that region (tab. 3).

The structure of researched households in each region did not change significantly in the years 2010-2019. However, the changes concern much more significant, regarding incomes and expenditures, characteristics of demographic type, determining an average number of people (and at the same time, consumption and equivalent units). In this respect, the Eastern region, where the number of persons constituting one household, as well as equivalent units the highest in the country, definitely features above the national average, as well as in relation to regions $(2,75$ and 1,79$)$. Those significant demographic factors are important, explanatory determinants ${ }^{18}$ of the level, as well as dispersion of income and expenditure in individual regions of Poland (fig. 7).

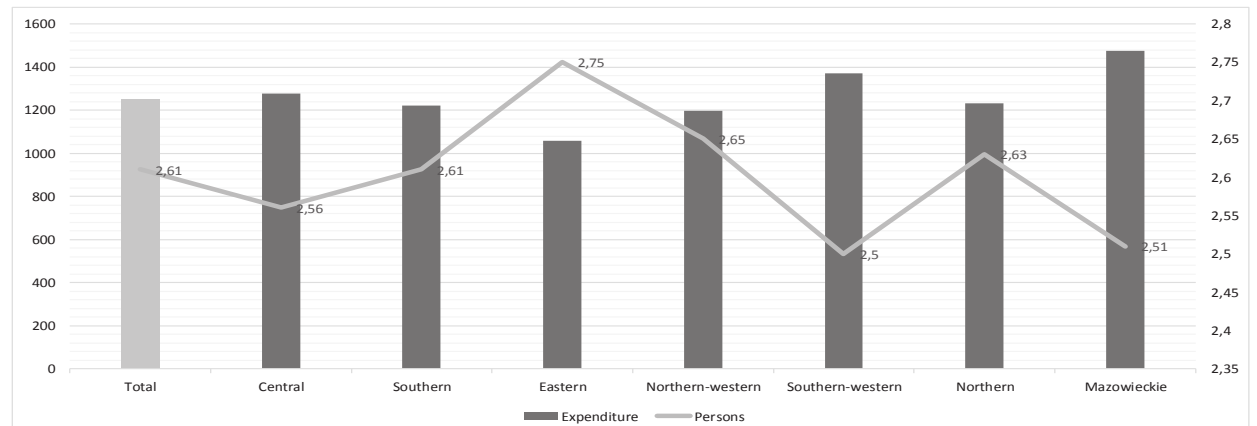

Figure 7. Average monthly expenditure in total per person (in PLN) and the average number of persons in a household per regions in Poland in 2019

Source: Own elaboration based on data published by Central Statistical Office of Poland www.stat.gov.pl [accessed May 19, 2021].

Notably, the final positions of the Eastern region in the rating according to the income and expenditure level result from other characteristic findings of the composition of households in that area - the highest average number of persons receiving social benefits and relying on the support of employed persons ${ }^{19}$.

${ }^{17}$ Comp. Budżety gospodarstw domowych, GUS, Warszawa, year 2011, 2020.

18 Comp. K. Hanusik, U. Łangowska-Szczę́niak: Determinanty poziomu i zróżnicowania dobrobytu gospodarstw domowych w Polsce w latach 2004-2012, „Zeszyty Naukowe Uniwersytetu Szczecińskiego”. Studia i Prace Wydziału Nauk Ekonomicznych i Zarządzania, 35(2)/2014, pp. 311-327.

${ }^{19}$ Comp. M. Leszczyńska, B. Kasprzyk: op.cit.s.263-273. 
Therefore, basic parameters of the distribution of income and expenditure provide us with a conclusion that the households in the Eastern region: possess the lowest level of economic prosperity and weak financial welfare position these households is closely related to the demographic factor.

\section{Conclusions}

A retrospective analysis for the years 2000-2019 within the income of the population of Poland indicates an increase of the average income in a nominal aspect (more than doubled), while decidedly lower in a real aspect (in the range of $93 \%$ ). The tempo of growth of income in the analysed years in Poland may be considered as moderate. The increased incomes have been generated increased expenditures, particularly in the consumption of consumable goods and services and savings accumulation. It finally implied household economic prosperity growth and welfare, in a purely economic aspect.

On the basis of the estimated parameters of analytical functions of the trend for the researched variables, it has been established that during the analysed period monthly income per person was increasing annually by 29 PLN on average, while the expenditure growth was slower, by 13 PLN on average. A positive tendency proves to concern the increasing angle of variation of average income and expenditure per person. Increasing surplus of incomes over expenditures gives the households an excellent perspective for savings.

Regional comparative analysis of households allows to draw conclusions indicating a very diversified level of economic condition with regards to the place of residence. There still are relatively large nominal and real income and expenditure deviations in Poland. The data findings undeniably indicates, that the lowest level for the analysed categories of economic prosperity concerns the Eastern region households, while the highest level concerns the macroregion Mazowieckie. In the Eastern region disposable income is lower by about $14 \%$ in relation to an average income on the national scale. A slightly smaller, but similar variation concerns expenditures.

In eastern Poland from 2010 to 2019, the difference of expenditures increased in relation to the national average and in terms of income it has decreased. Apparently, the range between the lowest (eastern region) and the highest (voivodship Mazowieckie) incomes and expenditures per person in the regions decreased over the analysed period by 8 percentage points on average.

The final positions of 'The Eastern Poland' in the rating of regions with respect to the level of disposable income and expenditure, in total, per person prove to be mainly the result of socio-economic-demographic factors determining the characteristic features of household composition within that region - they constitute the highest number.

Although the expenditure share in disposable income still varies among regions, from 2010 to 2016, the indicator noted decreasing tendency, so in the regional regard, we can notice a positive trend. That implies, that an increasing share of the incomes in households can be saved or allocated for repayment of financial liabilities.

It is worth to add, that the period of the COVID-19 pandemic started in March 2020 goes beyond the time frame, adopted in this article. However, this pandemic situation may could have a significant impact on the presented research results, showing the 
material situation in a different view. This new unexpected situation also indicates the need to look at the presented issues from the perspective of a crisis situation.

\section{References}

Abramczyk D.: Społeczne, demograficzne, ekonomiczne i geograficzne uwarunkowania zarządzania budżetem domowym w Polsce, Uniwersytet Marii Curie-Skłodowskiej w Lublinie, „Finanse i Prawo Finansowe” 3(19)/2018, pp. 9-24.

Aczel A. D.: Statystyka w zarządzaniu, PWN, Warszawa, 2000, pp. 624-627.

Babula E., Kamińska T.: Uwarunkowania dobrobytu $w$ sferze realnej, Published by: Wydawnictwo Uniwersytetu Gdańskiego, Gdańsk 2013.

Blajer-Gołębiewska A., Czerwonka L. (eds.): Mikro- i makroekonomiczne aspekty tworzenia dobrobytu, Published by: Uniwersytet Gdański, Gdańsk 2014.

Budżety gospodarstw domowych, GUS, Warszawa, consecutive years 2001-2020.

Bywalec Cz: Gospodarstwo domowe: ekonomika, finanse, konsumpcja, Wydawnictwo Uniwersytetu Ekonomicznego w Krakowie, Kraków 2017.

Cieślak M: Prognozowanie gospodarcze. Metody i zastosowania, PWN, Warszawa, 2012, pp. 7678.

Grzywińska-Rąpca M., Kobylińska M.: Regionalne zróżnicowanie dochodów gospodarstw domowych. „Wiadomości Statystyczne”, 64, 2019/12, pp. 46-57.

Hanusik K., Łangowska-Szczęśniak U.: Determinanty poziomu i zróżnicowania dobrobytu gospodarstw domowych w Polsce w latach 2004-2012, „Zeszyty Naukowe Uniwersytetu Szczecińskiego". Studia i Prace Wydziału Nauk Ekonomicznych i Zarządzania, 35(2)/2014, pp. 311-327.

Kahneman D.: International Differences in Well-Being, Series in Positive Psychology, Oxford University Press, New York 2010.

Kot S. M., Jakubowski J., Sokołowski A.: Statystyka, Published by: Difin S. A., Warszawa 2011, pp. 337-339.

Krajowa Strategia Rozwoju Regionalnego 2010-2020: Regiony, Miasta, Obszary wiejskie, Monitor Polski 2011, no. 36, pos. 423.

Leszczyńska M., Kasprzyk B.: Dochody i wydatki jako determinanty dobrobytu ekonomicznego gospodarstw domowych w Polsce -ujęcie regionalne, „Nierówności Społeczne a Wzrost Gospodarczy".,no. 28, 2012, pp. 263-273.

Ostasiewicz W.: Dobrobyt i jakość życia: badania w Polsce i zagranicą, „Śląski Przegląd Statystyczny" 11/2017, pp. 243-258.

Panek T.: Jakość życia gospodarstw domowych w Polsce w układzie wojewódzkim. Zeszyty Naukowe Instytutu Statystyki i Demografii SGH, 44/2015, pp.1-111.

Pizło W., Mazurkiewicz-Pizło A.: Regionalne zróżnicowanie dochodów gospodarstw domowych w Polsce, „Roczniki Naukowe Stowarzyszenia Ekonomistów Rolnictwa i Agrobiznesu” 16 96)/2014, pp. 397-402.

Regionalne zróżnicowanie jakości życia w Polsce, GUS, Warszawa 2017.

Regiony Polski, GUS, Warszawa, consecutive years 2011-2020.

Uchwała nr 8 Rady Ministrów z dnia 14 lutego 2017 r. w sprawie przyjęcia Strategii na rzecz Odpowiedzialnego Rozwoju do roku 2020 (z perspektywą do 2030 r.), Monitor Polski 2017, pos. 260.

Wronowska G.: Dobrobyt - ujęcie teoretyczne i pomiar, Zeszyty Naukowe „Cracow Review of Economics and Management" 12 (948)/2015, pp. 5-16.

Zaremba M.: Dobrobyt społeczny - problemy metodologiczne i definicyjne, „Nierówności Społeczne a Wzrost Gospodarczy" 4/2016, pp. 323-331.

Zeszyt metodologiczny. Badanie budżetów gospodarstw domowych, GUS, Warszawa 2018. 


\title{
Zmiany w zakresie dochodów i wydatków polskich gospodarstw domowych oraz ich relacje regionalne
}

\begin{abstract}
Streszczenie
W artykule dokonano oceny sytuacji finansowej gospodarstw domowych w latach 2000-2019 w świetle zmian dochodów i wydatków (w ujęciu nominalnym i realnym) w skali ogólnopolskiej i regionalnej. Jako punkt odniesienia przyjęto też, że kształtowanie się analizowanych zmiennych uzależnione jest od przestrzeni regionalnej. W analizie i porównaniach wykorzystano dane z badania budżetów gospodarstw domowych prowadzonych przez GUS. Przyjmując podejście ekonometryczne (uwzględniając zmienną czasową z lat 2000-2019 jako zmienną objaśniającą modeli) dokonano wyznaczenia analitycznych funkcji trendu dla badanych zmiennych. Jak się okazuje, w badanym przedziale czasowym istotnie poziom i dynamika dochodów oraz wydatków gospodarstw domowych w Polsce była zróżnicowana $\mathrm{z}$ wyraźną tendencją rosnącą. Różnice w dochodach i wydatkach dotyczyły także skali regionalnej, co udowodniono. Uwzględnienie w badaniach tego wymiaru wskazuje bowiem nadal na istnienie relatywnie wysokich odchyleń analizowanych kategorii pieniężnych. Pozytywnym wymiarem jest widoczny fakt poprawy przeciętnego poziomu sytuacji finansowej przeciętnego gospodarstwa domowego w Polsce.
\end{abstract}

Słowa kluczowe: dochody i wydatki, gospodarstwa domowe, ekonomiczny standard życia, analiza regionalna, finanse osobiste, nierówności społeczne

JEL codes: D12, D31, I31, R2

Information about the authors:

Małgorzata Leszczyńska Ph.D.

Department of Economics and International Economic Relation

Institute of Economics and Finance

College of Social Sciences

University of Rzeszow

35-601 Rzeszów, ul. Ćwiklińskiej 2

e-mail: leszczynska.malgorzata@wp.pl

ORCID: 0000-0002-8117-8788

Beata Kasprzyk Ph.D.

Department of Quantitative Methods and Economic Informatics Institute of Economics and Finance

College of Social Sciences

University of Rzeszow

35-601 Rzeszów, ul. Ćwiklińskiej 2

e-mail: bkasprzy@ur.edu.pl

ORCID: 0000-0003-4612-794X 